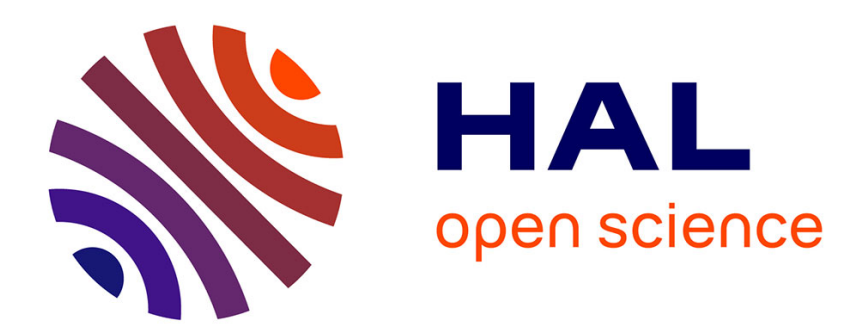

\title{
Octavian Augustus at Apollonia and the statement of his astrological sign
}

Amelia Carolina Sparavigna

\section{To cite this version:}

Amelia Carolina Sparavigna. Octavian Augustus at Apollonia and the statement of his astrological sign. 2019. hal-02267867

\section{HAL Id: hal-02267867 \\ https://hal.science/hal-02267867}

Preprint submitted on 19 Aug 2019

HAL is a multi-disciplinary open access archive for the deposit and dissemination of scientific research documents, whether they are published or not. The documents may come from teaching and research institutions in France or abroad, or from public or private research centers.
L'archive ouverte pluridisciplinaire HAL, est destinée au dépôt et à la diffusion de documents scientifiques de niveau recherche, publiés ou non, émanant des établissements d'enseignement et de recherche français ou étrangers, des laboratoires publics ou privés. 


\title{
Octavian Augustus at Apollonia and the statement of his astrological sign
}

\author{
Amelia Carolina Sparavigna ${ }^{1}$
}

1 - Dipartimento di Scienza Applicata e Tecnologia, Politecnico di Torino, Torino, Italy

\begin{abstract}
The article discusses a possible link between the astrological sign of the Capricorn, that Octavian Augustus chose as his symbol, and the constellation in which the sun was at the beginning of the calendar of Julius Caesar, that is the First January of 45 BC. Augustus may have chosen this constellation as the symbol of the birth of a new age, which Caesar, his adoptive father, had established with the reform of the calendar. The astrological sign was assigned to Octavian when he was in Apollonia, in the same year of the reform, 45 BC. The "magnus gubernator" of the world was born. Under the sign of Capricorn, Octavian Augustus ruled the empire.
\end{abstract}

Natus est Augustus M. Tullio Cicerone C. Antonio conss. VIIII. Kal. Octob., paulo ante solis exortum, regione Palati, ad Capita bubulo, ubi nunc sacrarium habet, aliquanto post quam excessit constitutum. This is told by Suetonius in his Life of Caesars. That is, Octavian was born in the year $63 \mathrm{BC}$. The year is given by the names of two Roman consuls. The day was 23 September. However, we know that the astrological sign of Augustus was not the Virgo or the Libra but the Capricorn. The Capricorn is the sign that we find on Augusts' coins and the standards of his legions. To have an agreement between the birthday on 23 September and the astrological sign, it is told that it was the sign when Octavian was conceived, that is, nine months before his birthday.
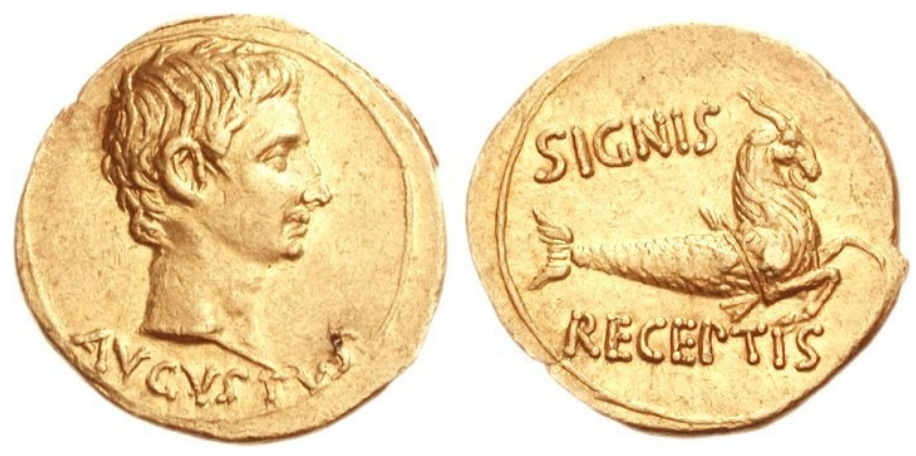

AV Aureus. Pergamum mint. Struck 19 BC. Augustus, bare head right. SIGNIS RECEPTIS, Capricorn right. Courtesy: CNG for Wikipedia. www.cngcoins.com/Coin.aspx?CoinID=115145 .

The problem is not only limited to this fact. It is much more complex. It is so complex that even Johannes Kepler was not able to solve it. When he was advisor to Emperor Rudolph II, the Emperor asked him to find Augustus birthday and his astrological sign. It was evident, to Rudolph and Kepler, that September 23 is not the true date of Augustus' birth (and we will see the reason in the following). After many calculations, the great astronomer wrote to his patron [1]: "Most noble 
lord, I have now for several weeks on end devoted my utmost efforts to the nativity of Caesar Augustus, about which your kingly majesty wishes to know, but, as I see, it has been almost in vain. For although it is no specially difficult task to calculate the configuration of the heavens for a particular time, nevertheless, what is lacking in the nativity we are now considering is that we no longer today know the correct time of it."

Rudolph had reasons for his request to Kepler. As told in [2], in spite of being born under the sign of Cancer, Rudolph adopted the Augustus" sign of Capricorn, "depicted by a creature with the tail of a fish. This symbol was placed on many works depicting Rudolf as the new Augustus as were the world Astrum fulget caesareum / the imperial star shines" [2]. Kepler spent a lot of time to find and combine the evidences given by the ancient authors on the date of Augustus' birth, in order to assess the role the Capricorn might have in his horoscope. As told in [1], he failed to find a solution.

It was impossible to Kepler to offer to the Emperor the solution given above, that is, the solution which is telling that the Capricorn was the sign when Octavian was conceived. Kepler could not fool the Emperor, who - and we can be sure of it - was well aware of the problems concerning the Roman chronology. Actually, the task was impossible, and Kepler explains the reason: "what is lacking in the nativity we are now considering is that we no longer today know the correct time of it".

So we have to search for a different solution to the problem. As we will see we can find it probably in the Julian Calendar itself.

Before the reform of Julian Caesar, Rome had a lunisolar calendar, which is known as the Republican Calendar. It was managed by the priests in a manner so irregular that the calendar was often designating dates, the dates that we can find in the historical reports, which are very different from the Julian dates. The Julian dates were proposed by Joseph Scaliger, a classical scholar, in 1583 at the time of the Gregorian calendar reform. He proposed his system as a method to solve chronological problems. The main problem - the equivalence of the historical dates, given in different calendars, and the Julian dates - was not simple. In Scaliger's approach, astronomical phenomena, such as the eclipses, were fundamental for establishing a chronology of the ancient world (see $[3,4]$ and references therein). An example: the lunar eclipse of 21 June 168 BC (Julian date) is reported in Livy's Ab Urbe Condita XLIV,37,5-9 at the date 3 September 168 BC of the Republican Roman calendar. We are at the time of the Pydna Battle.

Let us stress that, before $8 \mathrm{AD}$, the Julian dates are different of a few days from the dates of the Julian Calendar (see [5] and references therein).

The Julian reform was of 46 BC, and the new calendar started on the First January of 45 BC. At the time, Octavian was 18 years old. The year $46 \mathrm{BC}$ was the last of the old system and included 3 intercalary months, the first inserted in February and two more-Intercalaris Prior and Posteriorbefore the Kalends of December.

With Julius Caesar, the calendar became a solar calendar, which can be easily adjusted by adding just one extra day in the calendar every four years. This intercalation is necessary to compensate for the fact that the period of 365 days is shorter than the tropical year. The difference is of about six hours. The Republican calendar required the addition of a month, the Mercedonius, after February every two years. Occasionally, the intercalation happened every three years. Sometimes the intercalation was avoided or employed by the Roman priests for their political reasons, in spite of the state of the solar year.

Due to the possible large differences between the Republican calendar and the astronomical time, the birthdays of Roman people born before the first of January of $45 \mathrm{BC}$, were subjected to large uncertainties. In a certain manner, after the reform, many people had a different date for the birthday. Many of the Romans knew for sure that their birthday fell in a season different from that in which the birthday was falling according to the Julian calendar. 
Of the Republican calendar, the Julian reform did not change the method used to account days of the month, based on the Kalends, Nones and Ides, nor did it change the positions of these three dates within the months. But the length of the months was different. For this reason, after the reform of the Calendar, the Romans who were born after the Ides of a month, could decide differently about the change on their birthdays. "Mark Antony kept his birthday on 14 January, which changed its date from a.d. XVII Kal. Feb to a.d. XIX Kal. Feb, a date that had previously not existed. Livia [that became the second Augustus' wife] kept the date of her birthday unchanged at a.d. III Kal. Feb., which moved it from 28 to 30 January, a day that had previously not existed. Augustus kept his on 23 September, but both the old date (a.d. VIII Kal. Oct.) and the new (a.d. IX Kal. Oct.) were celebrated in some places." [6].

It is clear, from the irregularity of the Republican Calendar that it is highly probable that Octavian Augustus was not born on a day equivalent to September 23 of the Julian Calendar. No astronomical events, such as eclipses reported in historical records are given to find the proper equivalence, and this is the reason of Kepler's difficulties: we no longer today know the correct time of Augustus' birthday.

For what concerns Augustus' astrological sign, the Capricorn, in [7] it is told that "Suetonius and Manilius assert that Augustus was born under Capricorn". The astrological "domicile" of Saturn. In [7], it is also told that the "Capricorn was the sign of another vital moment in Octavian's life, and in the story of the mankind, as well: he received the laurel branches and the oak crown on January 13th, and the title of Augustus on January 16th, 27 BC, and in this very year the first coins with Capricorn were issued." Probably the first coin with the Capricorn on it was struck even before, about $40 \mathrm{BC}$. "The image of Capricorn is often accompanied by a cornucopia, one star, and a rudder, and sometimes it is holding the cosmic sphere. The cornucopia is not only an obvious symbol of abundance, but the peculiar symbol of a forthcoming, or newborn child." [7]

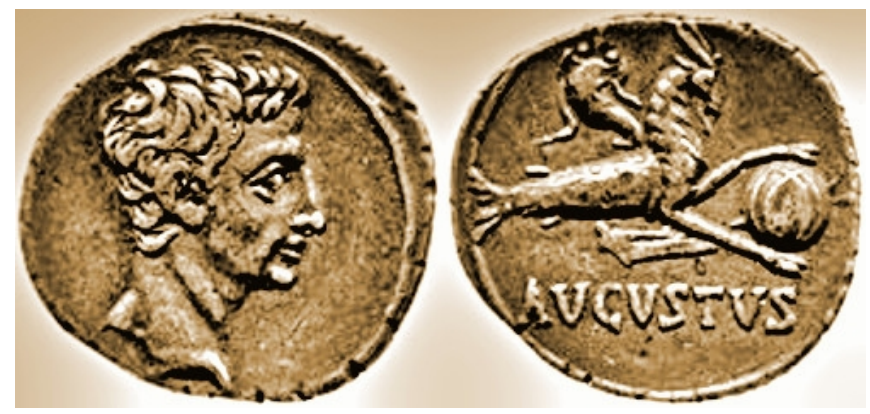

Coin from the British Museum. Image courtesy British Museum CC BY-NC-SA 4.0.

The image of the coin from British Museum shows the Capricorn, accompanied by a cornucopia and a rudder. The Capricorn is holding a globe that can easily be referred to Augustus' power over land and sea [1]. The same Capricorn, half goat and half fish, is representing Octavian Augustus ruling the land and sea. The symbol of the rudder is clear. Augustus was the ruler of the world, its magnus gubernator.

"Magnus gubernator et scisso navigat velo et, si exarmavit, tamen reliquias navigii aptat ad cursum." Seneca Epistulae ad Lucilium Liber IV. Un abile nocchiero sa navigare anche con la vela squarciata e, se ha perso il sartiame, tuttavia cerca di mantenere la rotta sfruttando quello che gli resta della nave. (Translation in Italian, Stefano Maso).

In any case, it is necessary to define when Octavian received his horoscope according to his astrological sign. The date of 23 September is a problem for us, as it was for Kepler. We can 
assume it as a conventional date, such as a conception nine months before birth. Accordingly, the Capricorn is a conventional sign. But, it could exist also another possibility.

Let us consider Augustus' life [8].

When Octavian turned 15, donned the toga virilis. Shortly after, he began his first official business upon being elected a pontiff in the College of Pontiffs. It was Julius Caesar who had nominated Octavian for this position. While celebrating the Festival of the Latins, Caesar appointed Octavian Praefectus Urbi until his return. From $46 \mathrm{BC}$ on, Octavian was very close to Caesar and attended theatres, banquets, and other social gatherings with him [8]. Octavian needed also experience with military affairs, and Caesar proposed that Octavian join him in Africa, even though the young man had fallen ill. Therefore, it was planned Octavian to join Caesar in Hispania. But Octavian again fell ill and was unable to travel. As soon as he was well, Octavian, with a few friends like Marcus Vipsanius Agrippa, sailed to Hispania. "He became shipwrecked and, after coming ashore with his companions, was forced to make it across hostile territory to reach Caesar's camp. Octavius' actions greatly impressed his great-uncle, who proceeded to teach Octavius the ways of provincial administration." [8] Caesar and Octavian stayed in Hispania until June 45 BC, after which they returned to Rome. Velleius Paterculus reports that Caesar and Octavian shared the same carriage [8]. In Rome, Caesar deposited a new will with the Vestal Virgins. He secretly named Octavian as the prime beneficiary. At the end of $45 \mathrm{BC}$, in order to improve Octavian's education, Caesar sent him, along with his friends Agrippa, Gaius Maecenas, and Quintus Salvidienus Rufus, to Apollonia in Macedonia. In Apollonia, Octavian learned academics and military doctrines. "Caesar, however, had more than just education in mind for Octavius. Macedonia was home of five legions and he hoped to use it as a launching ground for an upcoming war with Parthia in the Middle East." [8].

Apollonia in Macedonia is the location of the Suetonius' episode. "While in retirement at Apollonia, Augustus mounted with Agrippa to the studio of the astrologer Theogenes. Agrippa was the first to try his fortune, and when a great and almost incredible career was predicted for him, Augustus persisted in concealing the time of his birth and in refusing to disclose it, through diffidence and fear that he might be found to be less eminent. When he at last gave it unwillingly and hesitatingly, and only after many requests, Theogenes sprang up and threw himself at his feet. From that time on Augustus had such faith in his destiny, that he made his horoscope public and issued a silver coin stamped with the sign of the constellation Capricornus, under which he was born."

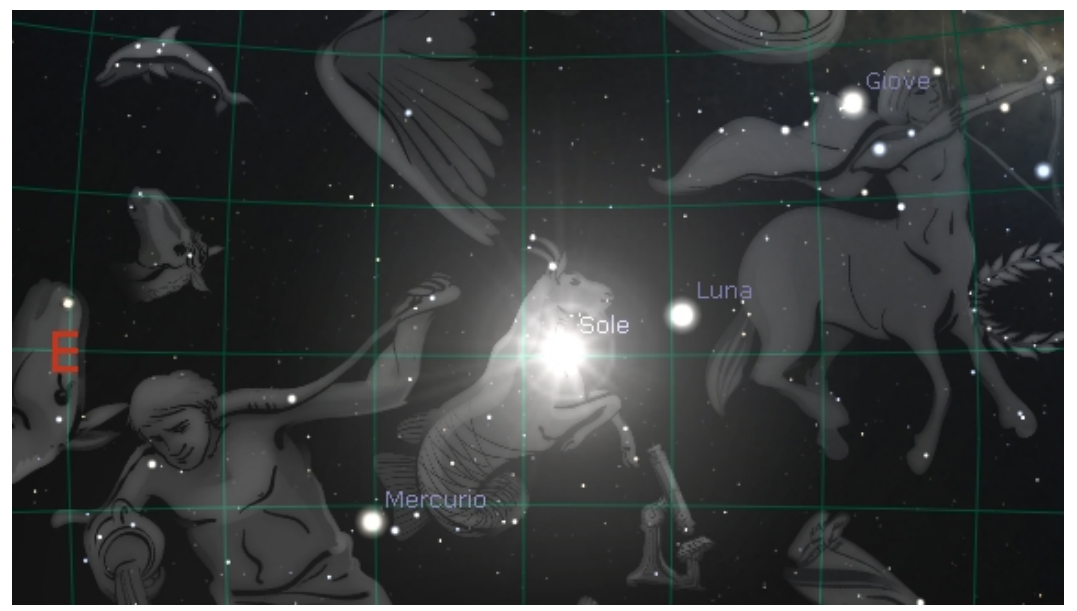

Screenshot software Stellarium showing the sun rising at Rome on the first of 1 January 45 BC. The sun is in the Capricorn. 
Augustus' reluctance to tell to Theogenes the date of his birth is perhaps also due to the fact that he was well aware that he could only tell a conventional date. The astrologer, with great intent - or because of a stroke of genius - convinced Octavian that his astrological sign was the Capricorn.

I am persuaded that it was a stroke of genius. The astrologer considered that the Capricorn was the constellation in which the sun was on the first day of the Julian Calendar, first of January 45 BC. As a consequence, Octavian Augustus received a symbol representing the birth of Julius Caesar's calendar as his astrological sign. The Capricorn became the symbol of the birth of a new age, an age that Caesar, Augustus' adoptive father, had established for the calendar, and Augustus was building with his empire. Moreover, the Capricorn was also the domicile of Saturn, and Saturn was the ruler of the Golden Age, a mythical time of prosperity and abundance. According to legends, during this age, the human beings lived without the need to cultivate the land, because it spontaneously gave all kinds of fruits to them. There were no wars. The climate was mild, giving to the world an eternal spring. With the advent of Jupiter, the golden age ended and the age of silver began. Therefore, the choice of Capricorn as astrological sign was perfect to represent, in Augustus' mind, the beginning of a new golden age, in the framework of his political propaganda that aimed to exalt his rule as a period of peace.

Note: A preliminary version of this paper has been proposed in Italian.

Sparavigna, Amelia Carolina. (2019, January 27). Il Calendario di Giulio Cesare e il Segno Zodiacale d'Augusto. Zenodo. http://doi.org/10.5281/zenodo.2550628

\section{References}

1. Barton, T. (1995). Augustus and Capricorn: Astrological polyvalency and imperial rhetoric. The Journal of Roman Studies, 85, 33-51.

2. Rudolph II and his world: A study in intellectual history 1576-1612 by R.J.W. Evans. Available at http://www.impossibleobjectsmarfa.com/fragments-2/rudolf-ii

3. Sparavigna, Amelia Carolina, The Eclipses in Livy's Ab Urbe Condita (July 11, 2019). Available at SSRN: https://ssrn.com/abstract=3428965 or http://dx.doi.org/10.2139/ssrn.3428965

4. Sparavigna, Amelia Carolina, On Dating the Lunar Eclipse of Alexander and the Battle of Gaugamela: Discussion of Evidence and Use of Archaeoastronomy for Chronology (June 30, 2019). Available at SSRN: https://ssrn.com/abstract=3412747 or http://dx.doi.org/10.2139/ssrn.3412747

5. Sparavigna, Amelia Carolina, The First Calends of the Julian Calendar (May 16, 2019). Available at SSRN: https://ssrn.com/abstract=3389310 or http://dx.doi.org/10.2139/ssrn.3389310

6. https://www.wikizero.com/en/Julian_Calendar

7. The Mysteries of Mithras: A Different Account. Attilio Mastrocinque. Mohr Siebeck, Aug 7, 2017. Pag. 249.

8. https://en.wikipedia.org/wiki/Early_life_of_Augustus 